\title{
Detection of IgM antibodies against Chlamydia trachomatis by enzyme linked fluorescence
} immunoassay

\author{
K NUMAZAKI, S CHIBA, T YAMANAKA, T MOROBOSHI, K AOKI, ${ }^{*}$ T NAKAO \\ From the Department of Pediatrics, Sapporo Medical College, Sapporo, 060 Japan, and the *Aoki Eye Clinic, \\ Sapporo, 003 Japan
}

SUMMARY A simple, sensitive enzyme linked fluorescence immunoassay has been developed to detect IgM antibodies against Chlamydia trachomatis. Reticulate bodies and elementary bodies from $C$ trachomatis $\mathrm{L}_{2} / 434 \mathrm{Bu}$ strain were isolated and used as antigens in the assay. Of 113 serum samples obtained from infants with pneumonia, $27(23.9 \%)$ had IgM antibodies to $C$ trachomatis $\mathrm{L}_{2}$ reticulate bodies and nine $(8.0 \%)$ had $\mathrm{IgM}$ antibodies to $C$ trachomatis $\mathrm{L}_{2}$ elementary bodies ( titre $\geqslant 1 / 500$ ). Specific IgM antibodies were not detected in 20 control serum samples obtained from healthy adults and children. The possible use of enzyme linked fluorescence assay to determine IgM antibodies in the serodiagnosis of $C$ trachomatis infection is discussed.

Chlamydia trachomatis causes a wide range of infections in adults and children, including trachoma, infantile pneumonia, neonatal inclusion conjunctivitis, non-gonococcal urethritis and other diseases of the eye and genital tract. $C$ trachomatis infection may be shown either by isolating the organisms in tissue culture or less often by serological means; in infantile pneumonia it is usual to make the diagnosis serologically.' In a previous study we isolated $C$ trachomatis from infants with pneumonia and detected IgM antibodies to $C$ trachomatis by the indirect immunofluorescence test. ${ }^{23}$

Up to now the most reliable technique for the serodiagnosis of $C$ trachomatis infection has been the microimmunofluorescence test of Wang and Grayston, ${ }^{4}$ which uses chlamydial elementary bodies as the test antigen. As this test requires specific antigens as well as trained personnel, it has not been readily available to small laboratories. Similar immunofluorescence tests using purified reticulate bodies or infected cells as the test antigen have also been described. ${ }^{5-7}$ More recently, chlamydial antibodies have been detected by means of an enzyme linked immunosorbent assay (ELISA). Lewis et $a l^{8}$ described an ELISA for measuring antibodies to $C$ psittaci, and Evans and Taylor-Robinson" used an ELISA to determine IgG and IgM antibodies to $C$ trachomatis based on passively absorbed extracted

Accepted for publication 25 January 1985 chlamydial group antigen. Mahony et $a l^{10}$ also described an ELISA for measuring IgG and IgM antibodies to $C$ trachomatis using Renografin purified $C$ trachomatis $\mathrm{L}_{2}$ elementary bodies grown in cycloheximide treated McCoy cells.

We have developed a simple, sensitive enzyme linked fluorescence immunoassay (ELFA) for measuring of IgG antibodies to $C$ trachomatis and have compared the results with those obtained with the ELISA and a microimmunofluorescence test for detecting serum IgG antibodies to $C$ trachomatis." This report describes the use of the ELFA to measure antichlamydial IgM antibodies in infants with pneumonia and in patients with a variety of diseases of the eye.

\section{Material and methods}

\section{SERUM SAMPLES}

Serum samples were obtained from 113 infants with pneumonia who were admitted to Sapporo Medical College Hospital and Hokkaido Children's Hospital during December 1981 to February 1984. The infants' ages ranged from 4 days to 2 years. Samples were also obtained from 37 patients with trachoma (stage VI), 21 patients with Behçet's disease, and 15 patients with acute follicular conjunctivitis attending eye clinics in Sapporo City. Patients were aged 20 to 80 years. In addition, samples were obtained from three sets of parents and a mother (aged 20 to 30 
years) attending eye clinics, in whose babies $C$ trachomatis had been found in conjunctival specimens. Serum samples were obtained from twenty age matched adults and children aged 0 to 80 years without infectious diseases to act as controls. All samples were frozen at $-20^{\circ} \mathrm{C}$ before being tested.

\section{ANTIGEN PREPARATION}

$C$ trachomatis $\mathrm{L}_{2} / 434 / \mathrm{Bu}$ was kindly provided by $\mathrm{Dr}$ Julius Schachter, University of California, San Francisco. The elementary body antigen used in the microimmunofluorescence test was prepared from HeLa 229 cells infected with the above strain as described elsewhere. ${ }^{2}$ Reticulate bodies were harvested from HeLa 229 cells after inoculation of the same strain of $C$ trachomatis by a modification of the procedure of Yong et al. ${ }^{6}$ After the cells had been disrupted by sonication, reticulate bodies were separated by differential centrifugation $(500 \mathrm{~g}$ for $10 \mathrm{~min}$ and $30000 \mathrm{~g}$ for $30 \mathrm{~min}$ ) and purified through a $30 \%$ Renografin cushion at $22000 \mathrm{~g}$ for $40 \mathrm{~min}$. The cells were then fixed in $6 \%$ formalin in phosphate buffered saline (PBS). For use in the ELFA, elementary bodies from $C$ trachomatis $\mathrm{L}_{2} / 434 / \mathrm{Bu}$ were harvested from HeLa 229 cells after inoculation and subjected to differential centrifugation as described above. The elementary body pellet was treated with RNase and DNase (Miles Laboratories, Illinois) at $37^{\circ} \mathrm{C}$ for $60 \mathrm{~min}$ before final separation on Renografin gradients. The elementary body pellet was then washed in PBS and suspended in PBS containing $0 \cdot 1 \%$ formalin. The reticulate body antigen used in the ELFA was prepared in the same way as for the microimmunofluorescence test. Antigen concentrations of $10 \mu \mathrm{g} / \mathrm{ml}$ for elementary bodies and $2.5 \mu \mathrm{g} / \mathrm{ml}$ for reticulate bodies were used in subsequent experiments.

\section{ELFA PROCEDURE}

Wells of a polyvinyl microtitration plate (B plate; Dynatech Laboratories) were coated with reticulate body and elementary body antigens, which had been diluted to the appropriate concentration in $0.05 \mathrm{M}$ carbonate and bicarbonate buffer ( $\mathrm{pH} \mathrm{9 \cdot 6).} \mathrm{After}$ incubation overnight at $4^{\circ} \mathrm{C}$, the plate was washed once with PBS (pH 7.3) and 0.05\% (vol/vol) Tween 20 (Sigma Chemical Company, St Louis, Missouri) (PBST). The wells were then filled with $100 \mu \mathrm{l}$ of $1.0 \%$ bovine serum albumin in PBS and left at room temperature for at least $4 \mathrm{~h}$ to block the remaining sites of the well. After this the wells were washed once with PBST and $100 \mu \mathrm{l}$ of diluted serum was added to each well. The plate was then incubated for $2 \mathrm{~h}$ at $37^{\circ} \mathrm{C}$ and washed five times with PBST. Next, $100 \mu \mathrm{l}$ of a $1 / 40000$ dilution in PBST of $\beta$-galactosidase labelled goat antihuman IgM
(Zymed Laboratories, South San Francisco, California) was added to each well. After further incubation for $2 \mathrm{~h}$ at $37^{\circ} \mathrm{C}$ the conjugate was removed by aspiration, and each well was washed five times with PBST. Substrate containing $0 \cdot 0025 \%$ 4-methylumbelliferyl- $\beta$-D-galactopyranoside (KochLight Laboratories, Colnbrook, Bucks) in $0.01 \mathrm{M}$ sodium phosphate buffer $(\mathrm{pH} 7 \cdot 0)$ was added to a volume of $100 \mu \mathrm{l} /$ well. The enzyme was allowed to act for $20 \mathrm{~min}$ and then stopped with $100 \mu \mathrm{l}$ of $0 \cdot 1$ $\mathrm{M}$ glycine and $\mathrm{NaOH}$ buffer. The fluorescence unit (FU) value of each well was determined with a Dynatech MicroFLUOR reader (1 fluorescence unit $=0.5 \times 10^{-12} \mathrm{M}$ methylumbelliferone) .

MEASUREMENT OF SERUM IgG AND IgM BY ELISA One hundred microlitres of commercial antihuman IgG and IgM antibodies (obtained from Dako Immunogloblin, Copenhagen, Denmark), diluted to the required concentration in carbonate and bicar-

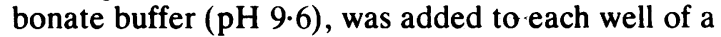
Nuncleon plate (Nunc, Denmark). The plate was incubated overnight at $4^{\circ} \mathrm{C}$ for passive absorption and washed once with PBST. The wells were then filled with $100 \mu \mathrm{l}$ of $1.0 \%$ bovine serum albumin in PBS and left at room temperature for $4 \mathrm{~h}$. Each well was washed once with PBST. Test samples were diluted in PBST and $100 \mu \mathrm{l}$ was added to appropriate wells. The plate was incubated for $2 \mathrm{~h}$ at $37^{\circ} \mathrm{C}$ and washed three times with PBST. Next, $100 \mu \mathrm{l}$ of a 1/2000 dilution of alkaline phosphatase conjugated goat antihuman IgG or IgM (Cappel Laboratories, West Chester, Pensylvania) was added to each well. After further incubation for $2 \mathrm{~h}$ at $37^{\circ} \mathrm{C}$ the conjugate was removed by aspiration, and each well was washed three times with PBST. Substrate, consisting of p-nitrophenyl-phosphate (1 $\mathrm{mg} / \mathrm{ml}), 50 \mathrm{mM} \mathrm{Na}_{2} \mathrm{CO}_{3}$, and $1 \mathrm{mM} \mathrm{MgCl}$ ( $\mathrm{pH} \mathrm{9.6),}$ was then added to a volume of $100 \mu \mathrm{l} / \mathrm{well}$. The plate was left at room temperature for $30 \mathrm{~min}$ after which time the reaction was stopped with $50 \mu$ l of 1 $\mathrm{N} \mathrm{NaOH}$. The absorbance at $405 \mathrm{~nm}$ was determined in a spectrophotometer.

SUCROSE DENSITY GRADIENT CENTRIFUGATION Half a millilitre of the test serum diluted $1 / 2$ was layered over $10 \mathrm{ml}$ of 12 to $36 \%$ (vot/vol) linear sucrose gradient and centrifuged at $100000 \mathrm{~g}$ for 20 h. Twenty fractions were collected with a density gradient fractionator (Hitachi $\mathrm{Co}$ ).

\section{MIF TEST}

The microimmunofluorescence test was performed with reticulate bodies and elementary bodies of $C$ trachomatis $\mathrm{L}_{2}$ as single antigens according to the methods described previously. ${ }^{4}$ 


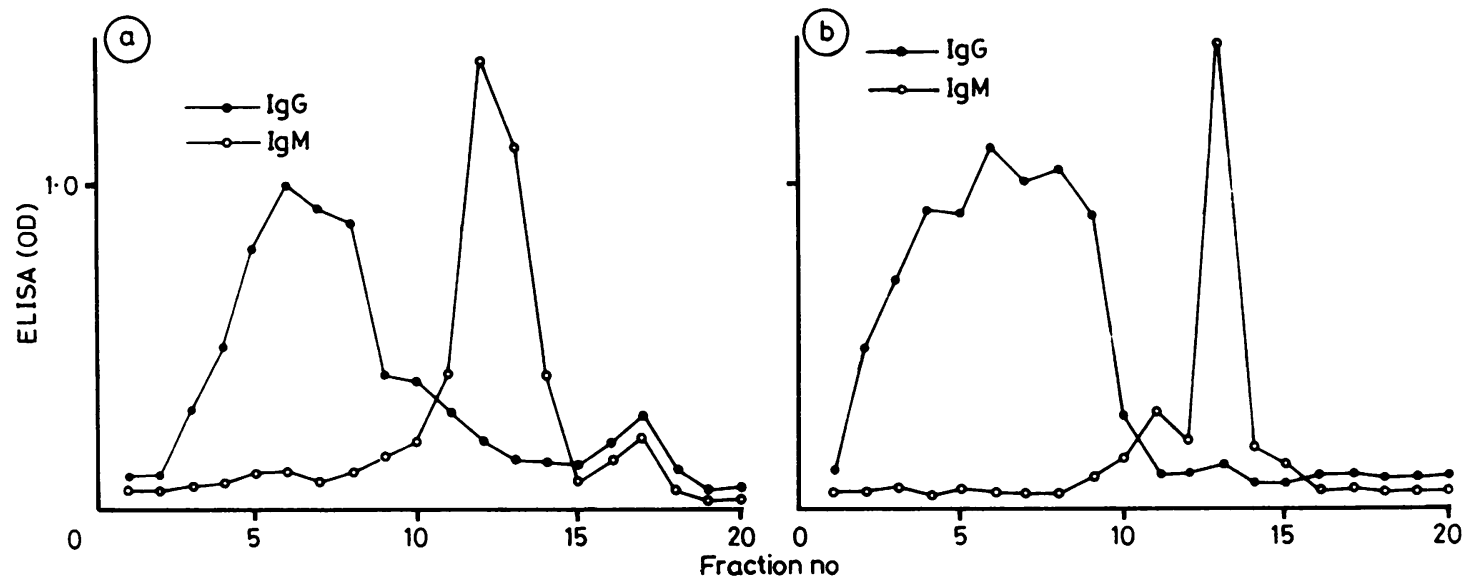

Fig. 1 Detection of serum IgG and IgM from Chlamydia trachomatis antibody positive (a) and antibody negative (b) serum by ELISA.

\section{Results}

\section{DETECTION OF ANTICHLAMYDIAL IgM}

ANTIBODIES BY ELFA AND COMPARISON WITH

ELISA TITRES AFTER SUCROSE DENSITY

GRADIENT CENTRIFUGATION

ELISA titres of serum IgG and IgM were determined in three IgM positive (titre, $\geqslant 1 / 36$ ) and three IgM negative samples against $L_{2}$ reticulate bodies and elementary bodies by means of the microimmunofluorescence test after sucrose density gradient centrifugation (Fig. 1). The main peak of IgG appeared in fractions 5 to 7 , and those of $\operatorname{IgM}$ appeared in fractions 11 to 13 . IgM antibodies to $C$ trachomatis $L_{2}$ elementary bodies and reticulate bodies were determined in microimmunofluorescence test positive and negative samples by ELFA at the dilution of $1 / 100$. The peaks that appeared in ELFA were roughly matched with the peak of IgM by ELISA. In microimmunofluorescence test negative sera no peak appeared by ELFA (Figs. 2 and 3). To investigate whether rheumatoid factor caused any false positive reactions with the IgM assay, three microimmunofluorescence test positive and three microimmunofluorescence test negative samples were tested. One of the microimmunofluorescence

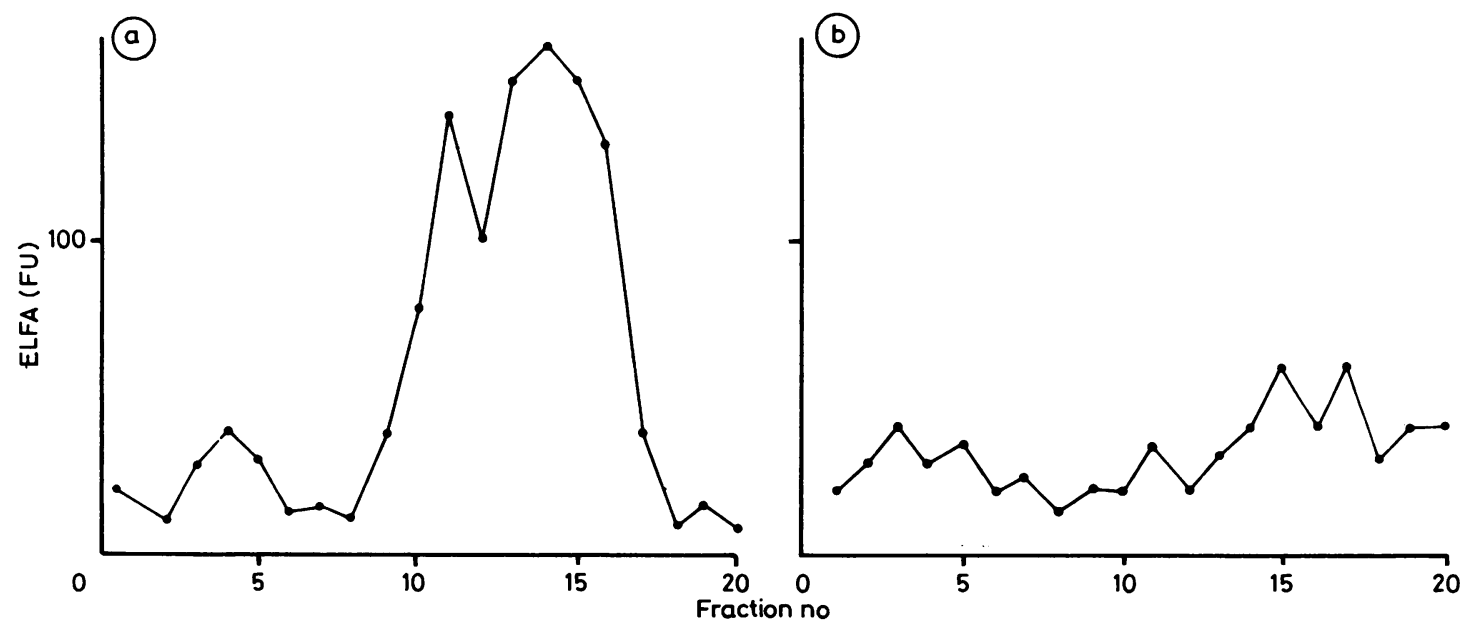

Fig. 2 Detection of IgM antibodies to $C$ trachomatis $L_{2}$ reticulate bodies from microimmunofuorescence test positive (a) and microimmunofuorescence test negative (b) serum by enzyme linked fuorescence immunoassay. 


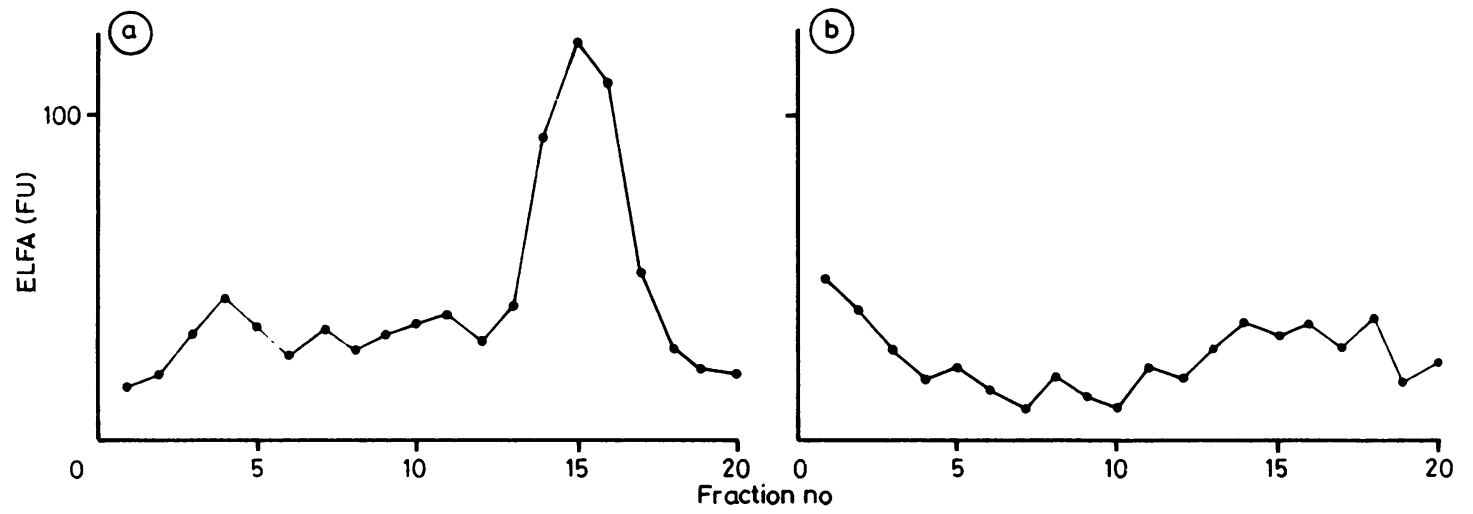

Fig. 3 Detection of IgM antibodies to $C$ trachomatis $L_{2}$ elementary bodies from microimmunofuorescence test positive (a) and microimmunofuorescence test negative (b) serum by enzyme linked fuorescence immunoassay.

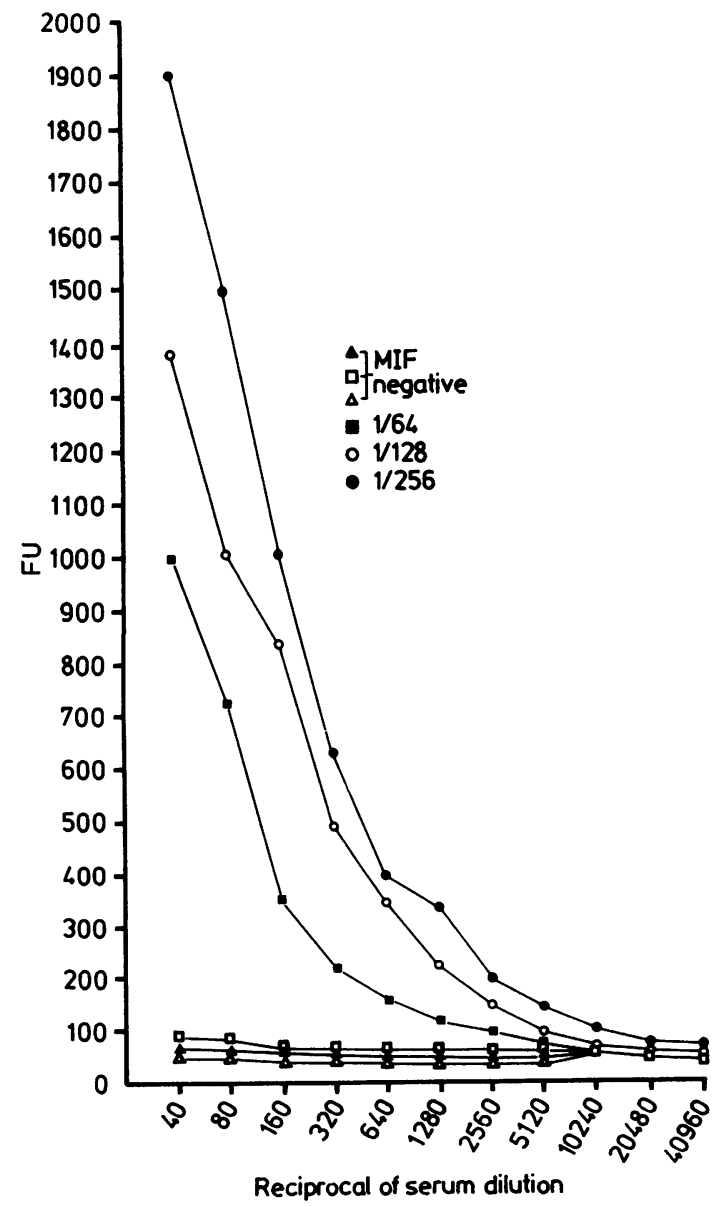

Fig. 4 Enzyme linked fuorescence immunoassay titration curve for serum IgM antibodies to Chlamydia trachomatis $L_{2}$ reticulate bodies.

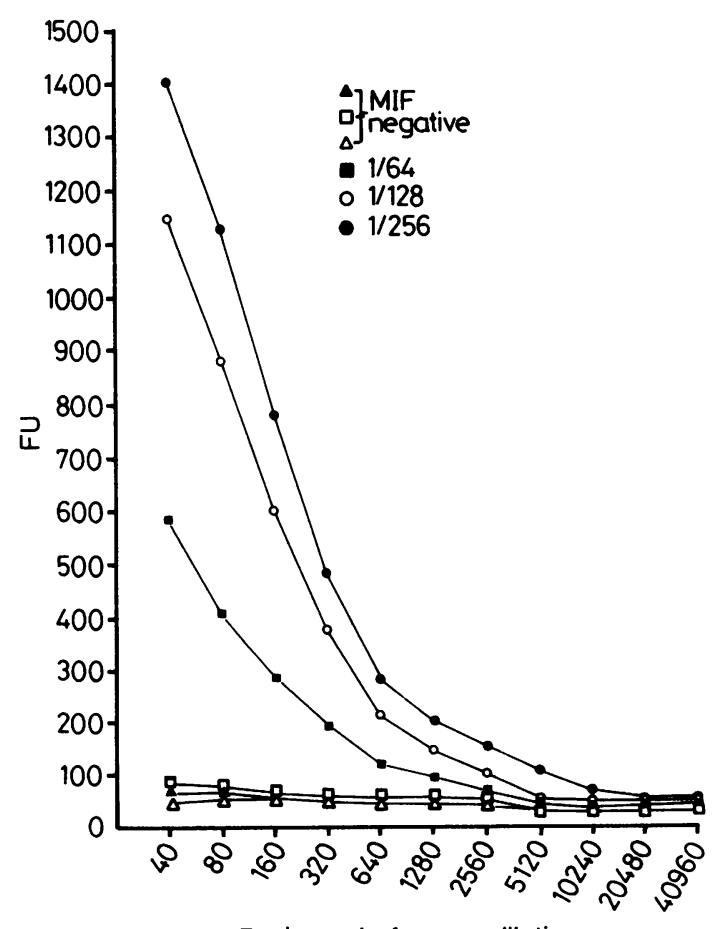

Reciprocal of serum dilution

Fig. 5 Enzyme linked fuorescence immunoassay titration curve for serum IgM antibodies to Chlamydia trachomatis $L_{2}$ elementary bodies. 
Seropositivity of IgM antibodies against Chlamydia trachomatis from different populations at the dilution of 1/500

\begin{tabular}{llll}
\hline Population & No tested & Reticulate body positive (\%) & Elementary body positive (\%) \\
\hline Pneumonia & 113 & $27(23.9 \%)$ & $9(8.0 \%)$ \\
Trachoma & 37 & $1(2.7 \%)$ & $0(0.0 \%)$ \\
Behçet's disease & 21 & $1(4.8 \%)$ & $1(4.8 \%)$ \\
Acute follicular conjunctivitis & 15 & $2(13.3 \%)$ & $2(13.3 \%)$ \\
Parents & 7 & $3(42.9 \%)$ & $2(28.6 \%)$ \\
Controls & 20 & $0(0.0 \%)$ & $0(0.0 \%)$ \\
\hline
\end{tabular}

test negative samples gave a positive reaction with the slide latex agglutination test for rheumatoid factor.

\section{POSITIVE AND NEGATIVE CONTROL CURVE TO ASSIǴN ELFA TITRES}

To establish cut off values of fluorescence units, which distinguished positive from negative samples, we determined the fluorescence unit value of each serum by subtracting the value shown on the control coated plates. Positive samples had values over three times the standard deviation for these negative samples. Based on these findings, we set the standard cut off value at 100 FU for ELFA (Figs. 4 and 5). Subsequent tests showed that this arbitrary cut off value did not compromise the sensitivity of the assay.

TITRATION OF HUMAN SERUM SAMPLES BY ELFA Of the 113 infants with pneumonia, $27(23.9 \%)$ had
IgM antibodies to $C$ trachomatis reticulate bodies (titre $\geqslant 1 / 500)$, and nine $(8.0 \%)$ had IgM antibodies to elementary bodies by ELFA (Table). Of the 37 patients with trachoma (stage VI), one $(2.7 \%)$ had IgM antibodies to reticulate bodies and none of them had IgM antibodies to elementary bodies. Of 21 patients with Behçet's disease, one $(4.8 \%)$ had antibodies to reticulate bodies and elementary bodies. Of the 15 patients with acute follicular conjunctivitis, two (13.3\%) had IgM antibodies to reticulate bodies and elementary bodies. Of the three parents and a mother of infants from whom $C$ trachomatis was isolated (from their conjunctival swabs), three had IgM antibodies to reticulate bodies and two had IgM antibodies to elementary bodies. On the other hand, none of the 20 age matched adults and children in the control group had antibodies either to reticulate bodies or to elementary bodies. The results for reticulate body

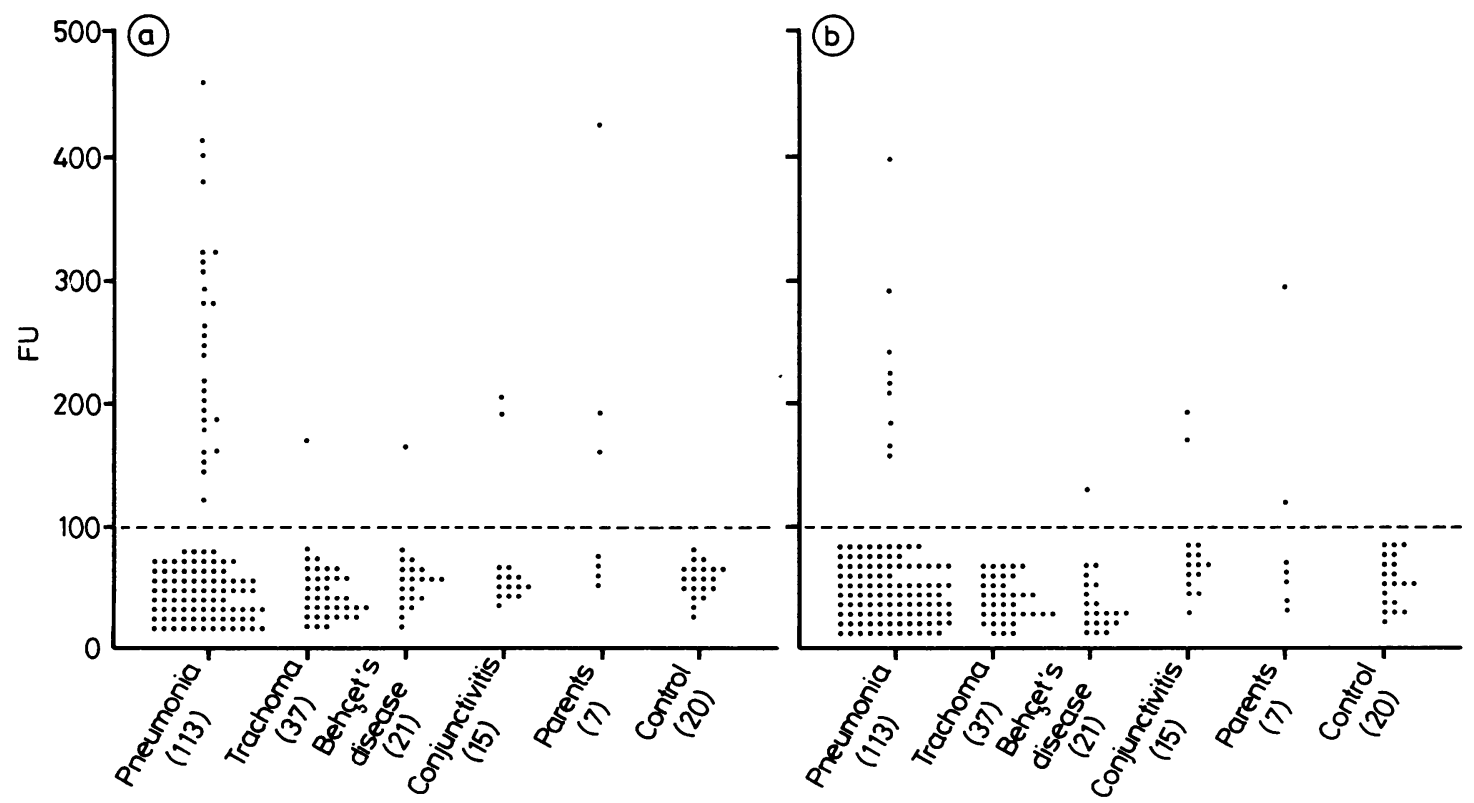

Fig. 6 Fluorescence unit (FU) in Chlamydia trachomatis $L_{2}$ reticulate bodies (a) and elementary bodies (b) enzyme linked immunofuorescence assays with serum from different populations at the dilution of $1 / 500$. 
and elementary body ELFA showed that the infants with pneumonia had higher fluorescence unit values than the other groups examined (Fig. 6).

\section{Discussion}

ELISA, originally described by Engvall and Perlmann ${ }^{13}$ and Van Weeman and Shuurs, ${ }^{14}$ has been used to detect antibodies to a number of infectious agents, including chlamydia. ${ }^{15-17}$ More recently, ELFA, using a fluorogenic substrate, has proved more sensitive than standard ELISA for detecting antibodies to some infectious agents. ${ }^{18}$ Yolken and Stopa $^{19}$ found that ELFA was about 100 times more sensitive than the corresponding ELISA or radioimmunoassay for the detection of human rotavirus in a standard stool suspension. ELFA has proved to be a simple, reliable, and sensitive method for the rapid detection of some infectious agents. ${ }^{20}$ There have been no reports, however, on the use of ELFA for the detection of IgM antibodies to $C$ trachomatis.

We have previously found that ELFA is a useful method for detecting IgG antibodies to $C$ trachomatis," and the present results suggest that specific IgM antibodies to $C$ trachomatis reticulate bodies and elementary bodies can be determined by ELFA. Although elementary body antigens from some strains have common antigenicity with other strains by ELISA, no elementary body antigen from a single immunotype can detect antibodies against all immunotypes of $C$ trachomatis. In contrast, reticulate bodies of $C$ trachomatis have group specific antigens shared by all immunotypes of $C$ trachomatis and by some strains of $C$ psittaci by ELISA. ${ }^{9}$ The same result was found in ELFA.

Serological tests are not particularly useful in the diagnosis of $C$ trachomatis infections except in patients experiencing their first episode of the disease. The chronic nature of $C$ trachomatis infections makes rising antibody titres a very unlikely finding. ${ }^{122}$

IgM antibodies to $C$ trachomatis are most likely to be detected in cases of systemic chlamydial infection, especially infantile pneumonia. The presence of high concentrations of IgM antibodies is not completely specific for the diagnosis of pneumonia in infants, as some infants who do not have pneumonia may develop high concentrations of these antibodies. Such cases occur in $0-1 \%$ of the population.'

In a previous study we isolated $C$ trachomatis from Japanese infants with pneumonia and detected IgM antibodies by the indirect immunofluorescence test. ${ }^{23}$ Subsequent tests showed good correlation between the isolation of $C$ trachomatis and the detection of IgM antibodies.
Of 109 infants with pneumonia, $32(29.3 \%)$ were positive for IgM antibodies (titre, $\geqslant 1 / 16$ ) by the indirect immunofluorescence test. $C$ trachomatis was isolated from $21(65.6 \%)$ of $32 \mathrm{IgM}$ antibody positive infants compared with five $(6.5 \%)$ of 77 IgM antibody negative infants. This study showed that about $24 \%$ of the infants with pneumonia had IgM antibodies to $C$ trachomatis $\mathrm{L}_{2}$ reticulate bodies (titre $\geqslant 1 / 500$ ).

Among patients with eye diseases (trachoma, stage VI, and Behçet's disease) and healthy controls concentrations of IgM antibodies against $C$ trachomatis were significantly lower. The meaning of the seropositivity of the patients with acute follicular conjunctivitis is unclear. The seropositivity of parents may be influenced by the presence of sexually transmitted diseases caused by $C$ trachomatis. The positive fluorescence unit values of infants with pneumonia were higher than in other groups tested. From these results, it would appear that the ELFA is group reactive or species reactive rather than type reactive.

The present results have shown the ELFA to be sensitive and able to determine accurately IgM antibodies against $C$ trachomatis from infants with pneumonia.

\section{References}

' Schachter J, Grossman M, Azimi PH. Serology of Chlamydia trachomatis in infants. J Infect Dis 1982;146:530-5.

${ }^{2}$ Numazaki K, Chiba S, Yamanaka T, Umetsu M, Nakao T. Isolation of Chlamydia trachomatis from Japanese infants with pneumonia. Acta Paediatr Jpn 1983;25:249-53.

${ }^{3}$ Numazaki K, Chiba S, Yamanaka T, Umetsu M, Nakao T Pneumonia due to Chlamydia trachomatis in Japanese infants. Tohoku J Exp Med 1984;143:413-20.

${ }^{4}$ Wang S-P, Grayston JT. Human serology in Chlamydia trachomatis infection with microimmunofluorescence. J Infect Dis 1974; 130:388-97.

s Thomas BJ, Reeve P, Oriel JD. Simplified serological test for antibodies to Chlamydia trachomatis. J Clin Microbiol 1976;4:6-10.

- Yong EC, Chinn JS, Caldwell HD, Kuo C-C. Reticulate bodies as single antigen in Chlamydia trachomatis serology with microimmunofluorescence. J Clin Microbiol 1979;10:351-6.

${ }^{7}$ Numazaki K, Chiba S, Nakata S, Yamanaka T, Nakao T. Prevalence of antibodies to Chlamydia trachomatis in Japanese persons determined by microimmunofluorescence using reticulate bodies as single antigen. Ped Infect Dis 1984;3:105-9.

${ }^{8}$ Lewis VJ, Thacker WL, Mitcell S. Enzyme-linked immunosorbent assay for chlamydial antibodies. J Clin Microbiol 1977;6:507-10.

${ }^{9}$ Evans RT, Taylor-Robinson D. Development and evaluation of enzyme-linked immunosorbent assay (ELISA), using chlamydial group antigen to detect antibodies to Chlamydia trachomatis. J Clin Pathol 1982;35:1122-8.

${ }^{10}$ Mahony JB, Schachter J, Chernesky MA. Detection of antichlamydial immunogloblin $G$ and $M$ antibodies by enzymelinked immunosorbent assay.J Clin Microbiol 1983;18:270-5.

"Numazaki K, Chiba S, Moroboshi T, Kudoh T, Yamanaka T, Nakao T. Comparison of enzyme-linked immunosorbent assay and enzyme linked fluorescence immunoassay for detection of 
antibodies against Chlamydia trachomatis. J Clin Pathol 1985;38:345-50.

${ }^{12}$ Kuo C-C, Wang S-P, Grayston JT. Growth of trachoma organism in HeLa 229 cell culture. In: Hobson D, Holmes KK, eds. Nongonococcal urethritis and related infections. Washington DC: American Society for Microbiology, 1977:328-36.

${ }^{13}$ Engvall E, Perlmann. Enzyme-linked immunosorbent assay (ELISA). III. Quantitation of specific antibodies by enzymelabeled anti immunogloblins in antigen coated tubes. $J$ Immunol 1972;109:129-35.

${ }_{14}$ Van Weeman BK, Schuurs AH. Immunoassay using antigen enzyme conjugates. FEBS Lett 1971;5:232-6.

is Finn MP, Ohlin A, Schachter J. An enzyme linked immunosorbent assay for IgG and IgM antibodies to Chlamydia trachomatis in human sera. J Clin Microbiol 1983;17:848-52.

${ }^{16}$ Levy NJ, Munoz A, McCormack WM. Enzyme-linked immunosorbent assay for the detection of antibodies to Chlamydia trachomatis and Chlamydia psittaci. J Lab Clin Med 1983;102:918-25.

17 Jones RB, Bruins SC, Newhall VWJ. Comparison of reticulate and elementary body antigens in detection of antibodies against Chlamydia trachomatis by an enzyme-linked immunosorbent assay. J Clin Microbiol 1983;17:466-71.
${ }^{18}$ Forghani B, Dennis J, Schimidt NJ. Visual reading of enzyme immunofluorescence assay for cytomegalovirus antibodies. $J$ Clin Microbiol 1980;12:704-8.

19 Yolken RH, Stopa PJ. Enzyme-linked fluorescence assay: ultrasensitive solid phase assay for detection of human rotavirus. $J$ Clin Microbiol 1979; 10:317-21.

${ }^{20}$ Yolken RH, Leister FJ. Comparison of fluorescent and colorigenic substrates for enzyme immunoassays.J Clin Microbiol 1982; 15:757-60.

21 Deelder AM, Koper G, DeWater R, Tanke HJ, Rotmans JP, Ploem JS. Automated measurement of immunogalactosidase reaction with a fluorogenic substrate by the apperture defined microvolume measurement method and its potential application to Schistosoma mansoni immunodiagnosis. J Immunol Methods 1980;36:269-83.

${ }^{22}$ Schachter J, Cles L, Ray R, Hines PA. Failure of serology in diagnosing chlamydial infections of female genital tract. J Clin Microbiol 1979; 10:647-9.

Requests for reprints to: Dr Kei Numazaki, Department of Pediatrics, Sapporo Medical College, S1 W16 Chuoku, Sapporo, Japan. 